\title{
The Effect of Socio-affective Strategies on Students' Test Anxiety across Different Genders
}

\author{
Mahnaz Saeidi \\ Department of English Language, Tabriz Branch, Islamic Azad University, Tabriz, Iran \\ Salam Khaliliaqdam \\ Department of English Language, Tabriz Branch, Islamic Azad University, Tabriz, Iran
}

\begin{abstract}
In the school setting, anxiety is often experienced by students when the students are evaluated, such as when they are taking a test or giving a public performance. When test anxiety is harsh, it can have outstanding negative effects on a student's ability to carry on at an optimum level. The purpose of this study is to investigate the effect of socio-affective strategies on male and female high school students' test anxiety across different genders. The participants of the study were 100 EFL Iranian students, including 56 male and 44 female, aged 15-16. The students were selected randomly and divided into four groups. The experimental groups consisted of one male class and one female class. Likewise, the control groups included one male class and one female class. In experimental groups, the teacher used socio-affective strategies; however, in control groups, no socio-affective strategies were used. The results of the ANCOVA statistical analysis indicated that there is a significant difference between experimental and control groups in terms of level of anxiety. Another finding of the study revealed that the difference between test anxiety of male and female was significant. The results of this study might be of interest for practitioners, especially, material developers and teachers in terms of various input-oriented tasks enriched by socio-affective strategy-based tasks to increase learners' autonomy and lower their test anxiety.
\end{abstract}

Index Terms - socio-affective strategies, test anxiety, gender

\section{INTRODUCTION}

Anxiety refers to an uncanny emotional condition in which one feels danger, loses power and experiences tension exposing an expected danger. Anxiety associated with foreign or second language learning and communication has long been in the focus of second language (L2) researchers (Ellis 1994). It has been investigated in the broader context of individual learner differences potentially responsible for differential success at language learning since the 1970s (Dörnyei, 2005). Gardner and MacIntyre (1993) describe L2 anxiety as the perception experienced when a situation in which the individual is required to use the second language but he is not enough proficient. Thus, according to Gardner and MacIntyre (1993), L2 anxiety is described as a situation-specific anxiety. As a result, test anxiety is an an uncomfortable emotional state in evaluation. Test Anxiety is a fear of not being successful in test situations and an uncanny feeling learners experience consciously or unconsciously in many situations (pp. 157-194). It is a kind of anxiety considering apprehension over academic evaluation resulting from a fear of not being successful (Horwitz \& Young, 1991).

According to Dörnyei (2005), differential success is due to individual learner differences. Test anxiety came from fear of failure. It is thought that they have investigated the source of unsuccessfulness in the exam, but they have not presented a strategy to reduce test anxiety Horwitz and Young (1991). The purpose of the present study is to examine the role of socio-affective strategies used by teachers on learners' test anxiety across gender.

\section{A. Statement of the Problem and Purpose of the Study}

There are many students who suffer from the day of the exam. They have studied well and they have been taught well but they are as well afraid of exam and they can't be successful as they expect themselves. A study by Horwitz and Young (1991) showed that test anxiety is a kind of anxiety considering apprehension over academic evaluation resulting from a fear of not being successful. Most learners study well and hard before they take an exam; they have confidence in what they have studied and what they have learned but they are afraid they can't take an exam as well as they expect themselves. The studies have revealed that the source of this test anxiety is due to the failure of not getting good marks. The problem is that why the learners are worried about not getting a good mark on the exam, although they have studied well and hard.

Ohata's study (2005) proved that most of the learners told that they were afraid of taking tests, because test-taking situations would have them be worried about the negative result of getting a bad mark. But there might be another source of this anxiety which makes the students fear getting a bad grade. Maybe the socio-affective strategies which the teachers apply in their classes are the source of this test anxiety. 
The aim of this study is to examine the effect of socio-affective strategies, used by teachers in the class, on learners' test anxiety. The end of the study, as well, is to know whether the socio-affective strategies which teachers use in the classroom affect the learners' test anxiety and the researchers are to examine learners' test anxiety across genders.

\section{B. Significance of and Justification for the Study}

Learners of English as a foreign language are well aware of the fact that despite of the fact that they have studied well and hard, they have not got good grades thanks to test anxiety. Language anxiety is a specific complex of selfawareness, beliefs, feelings and behaviors related to classroom language learning coming from the uniqueness of language learning process (Horwitz et al., 1986).

According to Chastain (1975), there was a negative correlation showing that greater successfulness was due to low test anxiety. As O'Malley and Chamot (1990) mentioned, by means of socio-affective strategies, language learners can lessen anxiety by utilizing some mental techniques and solve problems through teacher-student or peer interactions. Therefore, socio-affective strategies used by teachers, similarly, can be regarded as a useful strategy to accelerate students' interaction with the teacher in the classroom, which might lead to students' lowering of anxiety.

\section{Research Question and Hypothesis}

Young (1991) reported that studying long hours for a test made the students be worried about question types with which they had no exposure. Anxiety associated with foreign or second language learning and communication has long been in the focus of second language (L2) researchers. It has been investigated in the broader context of individual learner differences potentially responsible for differential success at language learning since the1970s (Dörnyei, 2005).

Moreover the assumption of the study is to examine whether the socio-affective strategies utilized by teachers in the classroom lead to learners' test anxiety or not. To this end, the two following research questions are asked:

1. Is there a difference between test anxiety of the learners exposing the socio-affective strategies and the test anxiety of those not exposing socio-affective strategies?

2. Is there a difference between test anxiety of male and female learners exposing the socio-affective strategies?

And the following hypotheses, accordingly, were formulated:

1. There is no difference between test anxiety of the learners exposing the socio-affective strategies and the test anxiety of those not exposing socio-affective strategies.

2. There is no difference between the test anxieties of male and female learners exposing the socio-affective strategies.

\section{REVIEW OF THE RELATED LITERATURE}

According to Ellis (1994), Anxiety refers to an uncanny emotional condition in which one feels danger, loses power and experiences tension exposing an expected danger. It is generally categorized into three types: Trait, state and situation- specific anxiety. Trait anxiety refers to an aspect of personality. State anxiety deals with an uncomfortable emotional state that is experienced as a response to definite situation. Finally, situation-specific anxiety is concerned with apprehension resulting from specific situations and events. Language anxiety, as an effective parameter that interferes achievement in L2 (Gardner, 1985), is a separate complex of self-understandings, beliefs, feelings and behaviors related to classroom language learning resulting from the uniqueness of language learning process (Horwitz et al.,1986).

A study by (Koralp, 2005) showed that EFL learners observed some English language learning anxiety on two anxiety level measures, being afraid of negative assessment and test anxiety, which were also positively correlated.

Vanin (2008) describes anxiety as when a student experiences extreme and uncontrollable worry about future and past happenings, overweening concern about performing pertinently and significant self-consciousness. Students with anxiety often have negative attitudes about their own ability to get along with stressful academic situations. They believe that they do not have the skills which are useful to adjust with a particular threat. Thus, they believe they monitor the situation or are losing their control over. Students who suffer from anxiety often misunderstood or boosted the importance of the situation.

Huberty (2009) claims that text anxiety overtime, tends to chip in more extensive underachievement. He describes the outcomes of severe test anxiety including lowered self-esteem, lessened effort, and loss of motivation for school tasks.

Silvestri (1986) reported that females have a greater likelihood of experiencing test anxiety. Some theorize that this is because society has different expectations for the genders. Many children are reared according to societal norms and mores that determine which roles are appropriate for which gender. Due to this biased upbringing, children perceive activities to be either masculine or feminine in nature. Excelling in an area that is not gender-appropriate often leads to punishment (Silvestri, 1986). This early conditioning encodes certain gender-specific behaviors and activities, as well as gender-specific expectations. Generally, males are expected to achieve in math, science, and technology, whereas females are reared to be interested in the arts (Silvestri, 1986). There has been some research to support the assertion that females are more test anxious with regard to math studies and have lower levels of test anxiety with regard to verbal exams than their male counterparts (Benson \& Bandalos, 1989; Dew \& Galassi, 1983; Meece, Eccles, \& 
Wigfield, 1990; Richardson \& Suinn, 1972; Rouxel, 2000; Wolters, Yu, \& Pintrich, 1996); however, in some other researches, these differences have been nonsignificant and slight (Hyde, J., Fennema, E., \& Lamon, S. 1990; Pajares \& Graham, 1999). It can be comfortably asserted that more research must be conducted to determine whether this is a result of gender-based differences in test anxiety or if the etiology is rooted in the different types of academic disciplines (Furst, Gershon, \& Weingarten, 1985).

According to Stern (1975, p. 311), "the concept of learning strategy is dependent on the assumption that learners consciously engage in activities to achieve certain goals and learning strategies can be regarded as broadly conceived intentional directions and learning techniques." All language learners use language learning strategies either consciously or unconsciously when processing new information and performing tasks in the language classroom. Since language classroom is like a problem-solving environment in which language learners are likely to face new input and difficult tasks given by their instructors, learners' attempts to find the quickest or easiest way to do what is required, that is, using language learning strategies is inescapable (Stern 1975).

Socio-affective strategies are the ones that are non academic in nature and deal with intriguing learning through setting up a level of empathy between the instructor and student. They consist of considering factors such as emotions and attitudes (Oxford, 1990). Socio-affective strategies strongly take into account the student's relation to society as a whole ranging from family to the global community. Tummala-Narra (2009) found that anxiety is experienced both by students and educators. To augment the effectiveness of learning, teachers are motivated to recognize anxietyprovoking situations and provide a helpful learning situation in order that the learners can devote their complete working memory resources to the learning tasks.

\section{METHOD}

\section{A. Participants}

The participants of the study were 100 EFL Iranian high school students, including 56 male and 44 female, aged 1516. The students were selected randomly out of 627 students and divided into four groups. The experimental groups consisted of one male class and one female class. The control groups included one male class and one female class. In experimental groups, the teacher used socio-affective strategies; however, in control groups, no socio-affective strategies were used.

\section{B. Instruments}

The book the students were studying was pre-university English one (2005). The Test-Anxiety questionnaire designed by Suinn (1969) was given to students in order to investigate the students' test-anxiety. A pretest including 10 Reading Comprehension questions, one cloze test consisting of 5 items, 3 grammar questions and 8 vocabulary questions was given to students in order that the researchers could be sure of homogeneity of the groups.

\section{Design}

This study is a quasi experimental research with pre-test, post test and control group. Socioaffective strategies used by the teacher is the independent variable and students' level of test anxiety is the dependent variable. In this study, ANCOVA was used to investigate the effect of socio affective strategies used by the teacher on students' test anxiety.

\section{Procedure}

The subjects were classified into four classes. Two classes including one male and one female class were considered as experimental groups while the other two classes consisting of one male and one female class were regarded as control groups. The subjects had English classes twice a week. Each session took 80 minutes.

The first session, a test anxiety questionnaire was given to the learners so as to be sure of their test anxiety level. The researchers wanted to know whether the control and experimental groups are at the same level or not. The second session, the teacher says hello to the students. He talks to them warmly, asks them if they are ready, happy, fine. Then the teacher answers the students' questions smoothly, explains the areas of difficulty on which the students have some problems. He also speaks about the exams the students are going to take during the course. He explains the role of the exams, the effects of the exams on the achievements of the students and very useful feedbacks which students will get from the exams. He finally explains the very important function of exams for language learning purposes. The teacher can see confidence, happiness, and relaxation on the students' face. The teacher sometimes lowers or raises his voice and respects the students' opinion. One of the students wants to comment on the exams, the teacher lets the student express what she is going to tell.

Then the teacher uses positive self-talk and encourages students to use the positive self-talk. An example of a positive self-talk is:

- I know that with hard work, I will pass the exam.

- I am prepared for this test and will do my best.

- I feel good about myself and my abilities.

- I am not going to worry about the difficult points. I'm going to use all my test time and check for careless errors. Even if I don't get the grade I want on this test, 'it is not the end of the world'. 
The teacher not only encourages the learners to use the above self-talks, but he also tries to help them not to use the negative self-talks at all. Whenever any student says, "I am too weak in English to pass the exam." The teacher tries to help him/her to be aware of his/her own ability. The teacher attempts to tell him/her "you can pass it; you are progressing well; I know you can prepare yourself for the exam well."

Sometime later the teacher gives the learners some samples to do together and cooperate with each other in doing the exercises. Having done the exercises together, the teacher tells them "these exercises are like the exam questions. How easy you can do them; on the exam you can solve problems very easily without the help from anyone." Finally the teacher checks their group work and write one hopeful sentence on their papers. Everyone is happy at the end of the class. The teacher assigns homework for the next session. Some more socio-affective strategies used by the teacher include the following:

- Encouraging students to share their anxiety with the group members and the teacher

- Using soft tone of voice and smile

- Encouraging positive thinking to increase students' self confidence

- Letting students know about their progresses

- Not criticizing students for their mistakes

- Using humor and creating cheerful atmosphere

\section{Data Analysis}

Having collected data, ANCOVA was used in order to find out if socio-affective strategies have any effects on test anxiety of learners. Having administered the pre-test of anxiety, the following results were obtained (Figure 1):

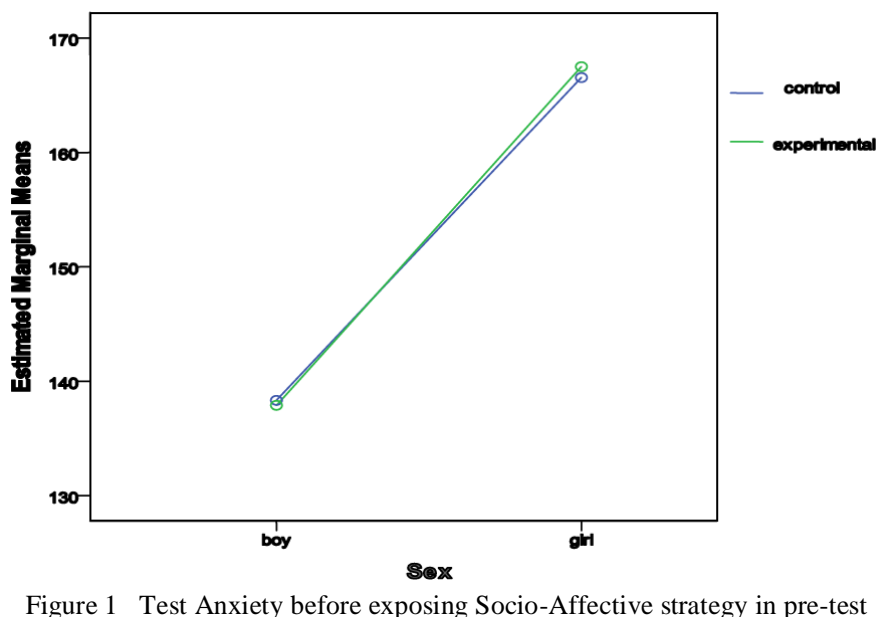

As depicted in Figure 1, there is no difference between female control and experimental groups in terms of test anxiety in pre-test. There is also no difference between male control and experimental groups in terms of test anxiety in pre-test. However, there was a difference between male and female's test anxiety before the instruction.

Table I shows the analysis of the results obtained from the Pre-Test and Post-Test. (Table I):

TABLE I

TEST ANXIETY AFTER EXPOSING STUDENTS TO SOCIO-AFFECTIVE STRATEGIES IN POST-TEST

\begin{tabular}{lllll}
\hline Source & Type III Sum of Squares & df & Mean Square & F \\
\hline Corrected Model & $84662.230^{\mathrm{a}}$ & 4 & 21165.557 & 101.596 \\
\hline Pre-test of Test Anxiety & 30778.766 & 1 & 30778.766 & 147.740 \\
\hline Gender & 378.683 & 1 & 378.683 & .000 \\
\hline Post-test of Test Anxiety & 44934.629 & 1 & 44934.629 & 215.688 \\
\hline Gender * SAS & 5896.120 & 1 & 5896.120 & .000 \\
\hline Error & 19374.801 & 93 & 208.331 & .181 \\
\hline
\end{tabular}

TABLE I I

THE EFFECT OF SOCIO-AFFECTIVE STRATEGIES ON TEST ANXIETY OF EXPERIMENTAL GROUPS (SAS)

\begin{tabular}{llllll}
\hline Source & Type III Sum of Squares & df & Mean Square & F \\
\hline Post-test of Test Anxiety & 44934.629 & 1 & 44934.629 & 215.688 \\
\hline
\end{tabular}

Table II shows that integrating socio-affective strategies in the classroom reduces the amount of anxiety which learners have when they face the exams.

The other important case which the results tell us is that the difference between test anxiety of male and female was significant ( $\mathrm{p}$-value $<0.00)$. That is to say, there is a relationship between gender and test anxiety. The results show that 
socio-affective strategies are gender-based. It means that the test anxiety of one group, female, has been reduced more than the male one (Table IV).

TABLE IV

THE RELATIONSHIP BETWEEN GENDER AND TEST ANXIETY OF EXPERIMENTAL GROUPS (SAS)

\begin{tabular}{llllll}
\hline Source & Type III Sum of Squares & df & Mean Square & F & Sig. \\
\hline Gender * SAS & 5896.120 & 1 & 5896.120 & 28.302 & .000 \\
\hline
\end{tabular}

\section{DISCUSSION}

Comparing the results among groups showed that socioaffective strategies used by the teacher resulted in decreasing students' test anxiety on the exam. This finding supports the results of Tummala-Narra (2009) who concluded that reducing test anxiety of the students resulted in increasing the learning achievement and effectiveness of the learning process. It also supports a study related to anxiety level of Turkish EFL learners done by Dalkilic (2001) emphasized the relationship between anxiety and achievement. In the study, test anxiety was not at the center of the study, but a parameter which influenced language anxiety.

Students' anxiety can be reduced greatly if instructors have a relaxed and positive error-correction attitude (Young 1999). Teachers' use of affective strategies such as humor, friendly relationship, supportive, and relaxed classroom atmosphere that encourage risk-taking are effective in decreasing foreign language anxiety and facilitating learning. Findings support the view that classroom teaching is a relational endeavor and experienced teachers emphasize the importance of warm socio-emotional atmosphere of the class (Wette 2010). It also supports Ohata (2005) who concluded that the test anxiety of students were lowered by the use of socio-affective strategies.

Comparing the mean of test anxiety scores between two experimental groups of male and female students shows that Female students have the highest test anxiety level. In addition, the test anxiety of female groups have decreased far more than that of male groups exposing to socioaffective strategies. Females reported significantly higher levels of test anxiety than males. This is consistent with the previous researches on gender effects on test anxiety (Mousavi \& Haghshenas \& Alishahi, 2008; Lashkaripour, 2006).

\section{REFERENCES}

[1] Benson, J., \& Bandalos, D. (1989). Structural model of statistical test anxiety in adults. In: H. van der Ploeg \& R. Schwarzer (Eds.). Advances in test anxiety research, (pp. 137-154). Hillsdale, NJ: Erlbaum

[2] Berger, R., \& Shechter, Y. (1996). Guidelines for choosing an "intervention package" for working with adolescent girls in distress. Adolescence, 31, 709-717.

[3] Bialystok, E. (1978). A theoretical model of second language learning. Language Learning, 28, 69-83.

[4] Chamot, A., \& Küpper, L. (1989). Learning strategies in foreign language instruction. Foreign Language Annals, 22 , 13-24.

[5] Chamot, A., O’Malley, J. M., Küpper, L., \& Impink-Hernandez, M.V. (1989). A study of learning strategies in foreign language instruction. First Year report, Rosslyn Interstate Research Associates.

[6] Chang, J. I. (1997). Contexts of adolescent worries: Impacts of ethnicity, gender, family structure, and socioeconomic status. Paper presented at the annual meeting of NCFR Fatherhood and Motherhood in a Diverse and Changing World, Arlington, VA.

[7] Chastain, K. (1975). Affective and ability factors in second language learning. Language Learning, 25, 153-161.

[8] Dalkilic, N. (2001). An investigation into the role of anxiety in second language learning. Unpublished Ph.D. Dissertation, Turkey.

[9] Dew, K., \& Galassi, J. (1983). Mathematics anxiety: Some basic cues. Journal of Counseling Psychology, 31, $581-584$.

[10] Dörnyei, Z. (2005). The Psychology of the language learner: Individual differences in second language acquisition. Mahwah, NJ: Lawrence Erlbaum Associates.

[11] Ellis, R. (1994). The Study of second language acquisition. Oxford: Oxford University Press.

[12] Everson, H. T., Millsap, R. E., \& Rodriquez, C. M. (1991). Isolating gender differences in test anxiety: A confirmatory factor analysis. Educational and Psychological Measurement, 51, 243-251.

[13] Feingold, A. (1994). Gender differences in personality: A meta analysis. Psychological Bulletin, 16, 429-456.

[14] Ferrando, P. et al. (1999). A psychometric study of the test anxiety scale for children in a Spanish sample. Personality and Individual Differences, 27(1), 37-44.

[15] Furst, D., Gershon, T., \& Weingarten, G. (1985). Test anxiety, sex, and exam type. Psychological Reports, 56, 663-668.

[16] Gardner, R.C., \& MacIntyre, P.D. (1993). On the measurement of affective variables in second language learning. Language Learning, 43, 157-194.

[17] Gardner, R.C., \& MacIntyre, P.D. (1993). On the measurement of affective variables in second language learning. Language Learning, 43, 157-194.

[18] Goh, C., \& Kwah, P.F. (1997). Chinese ESL students' learning strategies: A look at frequency, proficiency and gender. Hong Kong Journal of Applied Linguistics, 2, 39-53.

[19] Horwitz, E.K., \& Young, D.J. (Eds.). (1991). Language anxiety: From theory and research to classroom implications. Englewood Cliffs, NJ: Prentice Hall.

[20] Horwitz, E.K., Horwitz, M. B., \& Cope, J. (1986). Foreign language classroom anxiety. Modern Language Journal, 70(2), 125132.

[21] Huberty, T. (2009). Test and performance anxiety. Principle Leadership, 1(10), 15-19. 
[22] Hyde, J., Fennema, E., \& Lamon, S. (1990). Predictors of math anxiety and its influence on young adolescents' course enrollment intentions and performance in mathematics. Journal of Educational Psychology, 82, 60-70.

[23] Koralp, S. (2005). A retrospective analysis of the English language learning anxiety experienced by prospective teachers of English. Unpublished MA Thesis. Turkey.

[24] Lashkaripour, K. (2006). The relationship between test anxiety and academic achievement in students of guidance schools in Zahedan. Tabib Shargh Journal, 8th year, No 4, winter 85,70-71

[25] Mc Coy, D. (2006). Utilizing students' preferred language learning strategies for IELTS test preparation. EA Journal, 23 (1), 3 13.

[26] Meece, J., Eccles, J., \& Wigfield, A. (1990). Predictors of math anxiety and its influence on young adolescents' course enrollment intentions and performance in mathematics. Journal of Educational Psychology, 82, 60-70.

[27] Mehregan, F., Najjarian, B., \& Ahmadi, A. (2001). The relation between test anxiety and performance among Ahvaz university students. Ferdowsi J Psychol, 2, 7-24.

[28] Mousavi, M., Haghshenas, H., \& Alishahi, M.J. (2008). Effect of gender, school performance and school type on test anxiety among Iranian adolescents. Iranian Red Crescent Medical Journal, 10, 4-7.

[29] Ohata, K. (2005). Potential sources of anxiety for Japanese learners of English: Preliminary case interviews with five Japanese college students in the U.S. TESL-EJ, 9(3), $1-21$.

[30] O'Malley, J.M., \& Chamot, A. (1990). Learning strategies in second language acquisition. Cambridge: Cambridge University Press.

[31] Oxford, R. L. (1990). Language learning strategies: What every teacher should know. Heinle and Heinle Publishers. Boston Massachusetts.

[32] Pajares, F., \& Graham, L. (1999). Self-efficacy, motivation constructs, and mathematical performance of entering middle school children. Contemporary Educational Psychology, 24, 124-139.

[33] Richardson, F., \& Suinn, R. (1972). The mathematics anxiety rating scale: Psychometric data. Journal of Counseling Psychology, 19, 551-554.

[34] Rouxel, G. (2000). Cognitive-affective determinants of performance in mathematics and verbal domains of gender. Learning and Individual Differences, 12, 287-311.

[35] Silvestri, L. (1986). Achievement: Is it sex or situation specific? Journal of Instructional Psychology, 14, 74-82.

[36] Stern, H.H. (1975). What can we learn from the good language learner? Canadian Modern Language Review, 31, $304-318$.

[37] Stober, J. (2004). Dimensions of test anxiety relations to ways of coping with pre-exam anxiety and uncertainty. Anxiety, Stress, and Coping, 17, 213-226.

[38] Stowell, J., \& Bennett, D. (2010). Effects of online testing on student exam performance and test anxiety. Journal of Educational Computing Research, 42, 161-171.

[39] Suinn, R.M. (1969). The STABS, a measure of test anxiety for behavior therapy: Normative data. Behavior Research and Therapy, 7, 335-339.

[40] Tummala-Narra, P. (2009). Teaching on diversity: The mutual influence of students and instructors. Psychoanalytic Psychology, 26(3), 322-334.

[41] Vanin, J. (2008). Overview of anxiety and the anxiety disorders. Anxiety disorders: A pocket guide for primary care. Humana Press. Virginia.

[42] Wette, R. (2010). Professional knowledge in action: How experienced ESOL teachers respond to feedback from learners within syllabus and contextual constraints. System, 38(4), 569-579.

[43] Wolters, C., Yu, S., \& Pintrich, P. (1996). The relation between goal orientation and student's motivational beliefs and selfregulated learning. Learning and Individual Differences, 8, 211-238.

[44] Young, D.J. (1991). Creating a low-anxiety classroom environment: What does the language anxiety research suggest? Modern Language Journal, 75(4), 426-437.

[45] Zhi-hong, C. (2007). The effect of learning strategies on reading comprehension. The Journal of Sino-US English Teaching, $4(4), 15-18$.

Mahnaz Saeidi, Assistant professor of English language at Tabriz Branch, Islamic Azad University, Tabriz, Iran holds Ph.D. in Applied Linguistics (TEFL). She is the editorial board member of The Journal of Applied Linguistics, Tabriz, and the member of the Research Committee at the University. In 2007, 2008, 2009, 2010, and 2011 she won an award for being the best researcher. She has published several articles and books and participated in a number of inter/national conferences. Her major research interests are multiple intelligences, focus on form, feedback, and assessment.

Salam Khaliliaqdam is a Ph.D. student of TEFL at Tabriz Branch, Islamic Azad University, Tabriz, Iran. He has published articles in inter/national journals. He is an English language teacher. His major research interests are testing, anxiety, and formative assessment. 